\title{
Vietnamese Language
}

National Cancer Institute

\section{Source}

National Cancer Institute. Vietnamese Language. NCI Thesaurus. Code C120591.

An Austroasiatic language that is the native and official language of Viet Nam. 